\title{
Multiple environmental control of leaf area and its significance for productivity in beech saplings
}

\author{
Ann-Catrin Fender • Jasmin Mantilla-Contreras • \\ Christoph Leuschner
}

Received: 7 December 2010/Revised: 9 March 2011/Accepted: 19 March 2011/Published online: 5 April 2011

(C) The Author(s) 2011. This article is published with open access at Springerlink.com

\begin{abstract}
Climatic change exposes temperate trees to the simultaneous alteration of various growth-relevant factors, among them increased temperatures, extended growing season length and rising atmospheric $\left[\mathrm{CO}_{2}\right]$, often in combination with more severe droughts and reduced air humidities in summer, and elevated atmospheric $\mathrm{N}$ deposition. We conducted a multi-factorial climate chamber experiment to search for interactive effects of temperature $(T)$, soil moisture $(\theta)$, water vapour saturation deficit (VPD) and $\mathrm{N}$ availability (N) on the growth of Fagus sylvatica saplings and for identifying the most relevant factors that control leaf area development and productivity under a future warmer and drier climate with continuing high $\mathrm{N}$ deposition. For each of the four factors, two levels were simulated, reflecting current and expected future conditions in Central European beech forests. All four factors (including VPD) had a significant effect on productivity; several factors (e.g. $\mathrm{T} \times \mathrm{VPD})$ interacted in a synergistic way. Productivity was most tightly correlated with the number of leaves while leaf area was less influential and photosynthetic activity was of only minor importance. The number of leaves produced was most tightly correlated with $\theta, \mathrm{N}$ and VPD, while leaf area (leaf expansion) showed closest relation to temperature. We conclude that predictions
\end{abstract}

Communicated by T. Grams.

A.-C. Fender · J. Mantilla-Contreras · C. Leuschner $(\bowtie)$

Plant Ecology, University of Göttingen, Untere Karspüle 2,

37073 Göttingen, Germany

e-mail: cleusch@gwdg.de

Present Address:

J. Mantilla-Contreras

Institute of Botany and Landscape Ecology,

University of Greifswald, Grimmerstraße 88,

17487 Greifswald, Germany about the growth response of trees to climate change and altered atmospheric $\mathrm{N}$ deposition need to consider a multitude of environmental factors and must account for positive and negative factor interactions.

Keywords Air temperature - Climate change $\cdot$ Fagus sylvatica $\cdot$ Nitrogen availability $\cdot$ Soil moisture $\cdot$ VPD

\section{Introduction}

In future decades, climate change in conjunction with a relatively high atmospheric nitrogen $(\mathrm{N})$ deposition may alter the growth conditions of northern temperate forests in a fundamental way. If climate change scenarios become reality, the abiotic environment of Central European and Eastern North American forests will change in multiple directions: summer and winter temperatures $(T)$ will rise, the atmospheric $\mathrm{CO}_{2}$ concentration is about to double, and summer rainfall will decrease in many regions, which will expose the forests not only to periods of soil water $(\Theta)$ shortage but also to higher atmospheric water vapour saturation deficits (VPD) on average (IPCC 2007; Werner and Gerstengarbe 2007). Furthermore, in the industrialized regions of the temperate zone, it is likely that the atmospheric deposition of oxidized and reduced $\mathrm{N}$ compounds will remain relatively high for decades exposing the forests to high cumulative $\mathrm{N}$ loads that may accumulate in soil and biomass (Magnani et al. 2007). Thus, at least five environmental factors $\left(\mathrm{T},\left[\mathrm{CO}_{2}\right], \Theta, \mathrm{VPD}\right.$, and $\left.\mathrm{N}\right)$ with a putative effect on tree vitality and productivity may substantially change in future. Predictions about the expected response of trees and forests to these anticipated changes have to consider, among further drivers, these five factors and their mutual interactions. 
The response of temperate trees to altered $\left[\mathrm{CO}_{2}\right]$, temperature, soil moisture and nitrogen regimes has been investigated in numerous studies, mostly focussing on saplings or seedlings of the economically important trees (e.g. in Bazzaz and Miao 1993; Faria et al. 1996; van Hees 1997; Fotelli et al. 2000; Löf and Welander 2000; Palátová 2002; Peuke et al. 2002). In Central Europe, much research on the biological consequence of climate change concentrated on European beech (Fagus sylvatica L.), which dominates the potential natural forest vegetation and is also one of the key species in forestry. Beech seedlings and saplings were studied in their response to elevated $\left[\mathrm{CO}_{2}\right]$ (e.g. Heath and Kerstiens 1997; Bruhn et al. 2000; Kozovits et al. 2005), elevated temperature (Leverenz et al. 1999; Saxe and Kerstiens 2005; Overdieck et al. 2007), low soil moisture (Madsen 1995; García-Plazaola and Becerril 2000; Fotelli et al. 2001; Nielsen and Jørgensen 2003; Löf et al. 2005) and increased $\mathrm{N}$ availability (Flückiger and Braun 1999; Finzi and Canham 2000; Thomas et al. 2006). Most studies found significant growth responses to these factors. Lendzion and Leuschner (2008) further investigated the growth response of beech saplings to altered air humidity regimes. While these studies provided valuable insight into the physiological response of young beech plants to these environmental factors relevant in the context of global change, the bulk of investigations were singlefactor studies which ignored that various factors will change synchronously with possible positive and negative interactions between these elements of global change. In fact, many authors have concluded that multi-factor studies on the biological consequences of future environmental change are urgently needed. In the case of trees, this gap of knowledge has been addressed only in a few studies (e.g. Leverenz et al. 1999; Saxe and Kerstiens 2005; Sefcik et al. 2007). Multi-factor experiments, in particular those including 3, 4 or more factors, are especially valuable because they allow to identify key drivers among the multitude of influencing factors, and thus to distinguish between relevant factors and factors with a significant, but not relevant, influence only.

This study used a four-factorial climate chamber experiment with the goal to identify those environmental factors that will affect tree growth under predicted future climatic and $\mathrm{N}$-deposition conditions most severly. We chose Central Europe's most important indigenous tree species, Fagus sylvatica, for the experiment and altered air temperature, soil moisture, air humidity and soil $\mathrm{N}$ supply in a manner that should simulate a likely future environment for beech in parts of Central Europe under global change, i.e. with warmer and drier summers and a high $\mathrm{N}$ supply. We conducted a fully factorial experiment with 16 treatments to consider all possible interactions between these four factors. We measured not only productivity, but also analysed the response of various leaf area-related parameters, shoot-to-root ratio and net assimilation rate as well with the aim to identify the causes of the expected change in growth rate. The parameter values were chosen as realistically as possible to simulate current and expected future growth conditions of beech saplings in a forest.

We tested the hypotheses that (1) productivity of beech saplings is directly influenced by all four environmental factors including air humidity, and (2) leaf area and the processes of leaf area development (bud formation and leaf expansion) are key determinants of productivity, but are controlled by different environmental factors.

\section{Materials and methods}

\section{Plant material}

The experiment was conducted with 1-year-old saplings of European beech ( $F$. sylvatica L.) that were excavated in a beech forest on acid soil (Luzulo-Fagetum community) near Göttingen (N 51 34.62', E 10 3.76') in April 2007. The beech saplings had a size of about $15 \mathrm{~cm}$ and were carefully dug out with their complete root systems. To minimize possible effects of genetic variability, the saplings were collected from a limited forest floor area of $200 \mathrm{~m}^{2}$ where it is likely that the saplings represented the offspring of only 3-5 adult trees. In a greenhouse, the saplings were planted individually in pots of $3,600 \mathrm{~cm}^{3}$ volume filled with moist coarse sand. They were reared for 4 weeks prior to the onset of the experiment in a moist and cool environment as it is characteristic for many Central European beech forests in spring before leaf flushing. Air temperature was maintained at $7^{\circ} \mathrm{C}$ in the daylight period $\left(5^{\circ} \mathrm{C}\right.$ at night), vapour pressure deficit at $350 \mathrm{~Pa}(305 \mathrm{~Pa}$ at night), and photosynthetic photon flux density (PPFD) was about $170 \mu \mathrm{mol}$ photons $\mathrm{m}^{-2} \mathrm{~s}^{-1}$. The low temperature prevented the saplings to unfold their leaves before the beginning of the experiment. The experimental plants were selected according to their similarity in size from a larger collective of perspective test plants. The saplings chosen had a mean shoot length of $17.42 \pm 0.02 \mathrm{~cm}$ and an average number of leaf buds of $3.6 \pm 0.7$ when transferred to the climate chambers where the experiment took place.

\section{Experimental setup}

In a fully factorial experiment with four environmental factors (air temperature, soil moisture, air humidity and soil nitrogen) being manipulated, we grew the beech saplings for 87 days under controlled constant conditions in four walk-in climate chambers ([size $(l \times w \times h)]$ $4 \mathrm{~m} \times 4 \mathrm{~m} \times 2.5 \mathrm{~m}$, York, Johnson Control Systems, 
Essen, Germany). The effects of the four environmental factors $(T, \Theta$, VPD and $\mathrm{N})$ were examined with a nested split-plot design with four blocs (climate chambers). Air temperature and VPD were bloc variables ('pseudo-replicated' twice in each two chambers, though with nonmatching T and VPD conditions), while soil moisture and $\mathrm{N}$ supply were treated as sub-plot factors (10 replicates per treatment). The four climate chambers $\left(24^{\circ} \mathrm{C}, 1,000 \mathrm{~Pa}\right.$; $24^{\circ} \mathrm{C} 500 \mathrm{~Pa} ; 18^{\circ} \mathrm{C}, 1,000 \mathrm{~Pa}$ and $18^{\circ} \mathrm{C}, 500 \mathrm{~Pa}$ ) allowed accurate temperature $\left( \pm 2^{\circ} \mathrm{C}\right.$ with light, $\pm 1^{\circ} \mathrm{C}$ without light source) and humidity control ( $\pm 5 \%$ relative humidity) and a constant and homogeneous PPFD of $302 \pm 3 \mu \mathrm{mol}$ photons $\mathrm{m}^{-2} \mathrm{~s}^{-1}$ during daytime (Clean Ace, Eye Lighting International of North America Inc., Mentor, USA). This illumination is characteristic of larger gaps in Central European beech forests during springtime (Closa et al. 2010). Each two levels of a factor (current conditions, expected future conditions) were simulated, yielding $2^{4}=16$ treatments in the experiment (Table 1). Every treatment was conducted with 10 saplings grown individually in pots, giving 160 pots in total. In the current-conditions treatments, air temperature $(T)$, soil moisture $(\Theta)$, air humidity (VPD) and soil nitrogen (N) were maintained at levels that represent the characteristic thermal and humidity conditions in a Central European beech forest during mid-summer under non-limiting moisture conditions. In this treatment, temperature was maintained at $18^{\circ} \mathrm{C}$ in the 14 daytime hours (6 a.m. -10 p.m.) and at $10^{\circ} \mathrm{C}$ in the dark phase; the atmospheric saturation deficit (VPD) was $500 \mathrm{~Pa}$ in the light hours, and 300 and $293 \mathrm{~Pa}$ at 16 and $10^{\circ} \mathrm{C}$, respectively, in the dark period. These conditions mirror the microclimate in June/July in the beech forests close to Göttingen where Kriebitzsch et al. (1985) measured daytime air temperatures on the forest floor of about $18^{\circ} \mathrm{C}$ and daytime VPD means between 200 and $600 \mathrm{~Pa}$. A soil moisture of 12 vol.\% stands for ample soil moisture availability in the sandy substrate that was used in the experiment. The soil moisture content of the pots was adjusted three times per week by weighing the pots and calculating the difference between actual weight and the weight expected for soil moistures of 12 (or 6) vol.\%. The mass difference was expressed in millilitre water and added. Before rewetting, the soil moisture declined on average to $9.0( \pm 0.6)$ vol. $\%$ in the 12 vol. $\%$ pots and to $4.7 \pm 0.3 \mathrm{vol} . \%$ in the 6 vol. $\%$ pots. Additionally, soil moisture was monitored biweekly with a Theta probe (ML2x, Delta-T Devices Ltd., Cambridge, UK) in every pot. For T, $\Theta$, and VPD, we run treatments with expected future conditions under a changed climate, i.e. warmer summers $\left(24^{\circ} \mathrm{C}\right.$ in the daylight period, $16^{\circ} \mathrm{C}$ during night) with a reduced air humidity (a saturation deficit of $1,000 \mathrm{~Pa}$ during the day at 24 and $18^{\circ} \mathrm{C}$, and of 600 and $591 \mathrm{~Pa}$ at $16^{\circ} \mathrm{C}$ and $10^{\circ} \mathrm{C}$, respectively, in the dark period). Summer temperatures of $24^{\circ} \mathrm{C}$ with saturation deficits of $1,000 \mathrm{~Pa}$ may occur under the recent climate only occasionally on the forest floor of beech forests, for example on hot days in larger canopy gaps. The treatment with reduced soil moisture (6 vol.\%) exposed the beech saplings to a rather dry soil, but well above the permanent wilting point. Consequently, the warm, dry air and dry-soil treatment simulated conditions as they are expected to happen during exceptionally dry and warm summers associated with heat waves in Central Europe. Such heat wave events occur in our days only episodically (as in 2003), but are predicted to take place much more frequently at the end of this century according to recent climate change scenarios (Schär et al. 2004). For providing a continuous supply of nitrogen (and other elements) at predefined levels, we chose sand with a low cation exchange capacity as a growing medium and supplied nutrients with a nutrient solution $(0.2 \times$ Shive solution, Baumeister and Ernst 1978), that was added twice a week to the irrigation water. In the experiment, we simulated two levels of $\mathrm{N}$ availability, applying $25 \%$ of the $\mathrm{N}$ concentration of a $0.2 \times$ Shive solution, and a full $0.2 \times$ Shive solution, simulating the transition from moderately high atmospheric $\mathrm{N}$ deposition (i.e. $<15 \mathrm{~kg} \mathrm{~N}^{-1}$ year $^{-1}$ )

Table 1 The air temperature, air humidity, soil moisture and nitrogen supply conditions in the experimental treatments

\begin{tabular}{|c|c|c|c|c|}
\hline & Temperature $(\mathrm{T})$ & Air humidity (VPD) & Soil moisture $(\Theta)$ & Nitrogen supply (N) \\
\hline High (1) & $\begin{array}{l}24^{\circ} \mathrm{C} \text { daytime } \\
16^{\circ} \mathrm{C} \text { nighttime }\end{array}$ & $\begin{array}{l}\mathrm{VPD}=500 \mathrm{~Pa} \text { equals } 83.5 \% \text { rel. humidity at } 24^{\circ} \mathrm{C}^{\mathrm{a}} \\
\mathrm{VPD}=500 \mathrm{~Pa} \text { equals } 76.1 \% \text { rel. humidity at } 18^{\circ} \mathrm{C}^{\mathrm{b}}\end{array}$ & 12 vol. $\%$ soil water content & $<15 \mathrm{~kg} \mathrm{~N} \mathrm{ha}^{-1}$ year $^{-1}$ \\
\hline Low $(\mathbf{0})$ & $\begin{array}{l}18^{\circ} \mathrm{C} \text { daytime } \\
10^{\circ} \mathrm{C} \text { nighttime }\end{array}$ & $\begin{array}{l}\text { VPD }=1,000 \mathrm{~Pa} \text { equals } 67 \% \text { rel. humidity at } 24^{\circ} \mathrm{C}^{\mathrm{c}} \\
\mathrm{VPD}=1,000 \mathrm{~Pa} \text { equals } 52 \% \text { rel. humidity at } 18^{\circ} \mathrm{C}^{\mathrm{d}}\end{array}$ & 6 vol. $\%$ soil water content & $>25 \mathrm{~kg} \mathrm{~N} \mathrm{ha}^{-1}$ year $^{-1}$ \\
\hline
\end{tabular}

Each two levels of a factor were installed yielding $2^{4}=16$ treatments

a $83.5 \%$ relative equals $300 \mathrm{~Pa}$ at $16^{\circ} \mathrm{C}$ during nighttime

b $76.1 \%$ relative humidity equals $293 \mathrm{~Pa}$ at $10^{\circ} \mathrm{C}$ during nighttime

c $67 \%$ relative humidity equals $600 \mathrm{~Pa}$ at $16^{\circ} \mathrm{C}$ during nighttime

d $52 \%$ relative humidity equals $591 \mathrm{~Pa}$ at $10^{\circ} \mathrm{C}$ during nighttime 
to high inputs ( $>25 \mathrm{~kg} \mathrm{~N}^{-1}$ year $\left.^{-1}\right)$ as it took place or will soon occur in the larger part of Western Central Europe.

Determination of growth-related parameters

After 87 days of growth under defined conditions, the saplings were harvested and separated into shoots, leaves and roots. The leaves, shoots and washed roots were ovendried at $70^{\circ} \mathrm{C}$ for $48 \mathrm{~h}$. The dry weight of the different components was determined, and the total dry weight of each individual was calculated by adding the weight of shoot, leaves and roots. For estimating the dry matter production of the saplings, a reference dry weight of ten randomly chosen saplings was obtained at the first day of the study. Biomass production was calculated as the difference in dry weight at the beginning and at the end of the study by subtracting the mean initial dry weight of the reference plants from the plant's weight at harvest (Cernusak et al. 2009, Rodenkirchen et al. 2009).

Leaf area development was investigated by counting the number of leaves at the date of harvest and measuring total leaf area per sapling using a flat-bed scanner (Epson expression 1680, Long Beach, USA) and the image analysis software WinFolia 2005b (Régent Instruments, Quebec, Canada). Two randomly selected leaves per sapling were used to determine specific leaf area (SLA, in $\mathrm{m}^{2} \mathrm{~kg}^{-1}$ ). Foliar nitrogen content was measured in the ground leaf dry matter by $\mathrm{C} / \mathrm{N}$ elemental analysis (Vario III EL Elementar Analysensysteme GmbH, Hanau, Germany). Leaf area ratio (LAR, $\mathrm{m}^{2}$ leaf area $\mathrm{g}^{-1}$ plant mass) was obtained by multiplying SLA with leaf weight ratio (LWR, $\mathrm{g}$ leaf $\mathrm{g}^{-1}$ plant mass). Shoot-to-root ratio is the quotient of total aboveground to total below ground (root) dry mass.

Light-saturated net photosynthesis $\left(A_{\max }\right)$ was measured with a LI-6400 gas exchange system (Li-Cor Inc., Lincoln, USA) equipped with a standard leaf chamber and a 6400-02B LED red/blue light source. In a first step, we analysed the light response of ten randomly chosen fully expanded leaves of the experimental plants in the range up to $2,000 \mu \mathrm{mol}$ photons $\mathrm{m}^{-2} \mathrm{~s}^{-1}$, which showed that the shade-adapted plants reached $A_{\max }$ at irradiances of $1,200 \mu \mathrm{mol}$ photons $\mathrm{m}^{-2} \mathrm{~s}^{-1}$ or less. In the last week before harvest (i.e. from day 80 onwards), we determined $A_{\max }$ in each ten fully expanded leaves per treatment at similar position on the plants under standard conditions $\left(1,200 \mu \mathrm{mol}\right.$ photons $\mathrm{m}^{-2} \mathrm{~s}^{-1}, 360 \mathrm{ppm}\left[\mathrm{CO}_{2}\right], \quad 25^{\circ} \mathrm{C}$, $\mathrm{VPD}=1,901 \mathrm{~Pa}$, air flow rate $=0.5 \mathrm{mmol} \mathrm{s}^{-1}$ ). Prior to measurement, the leaves were allowed to acclimate to the measuring conditions for about $15 \mathrm{~min}$. In addition, net photosynthesis rate under ambient conditions in the chambers $\left(A_{\text {act }}\right)$ was measured in each 10 leaves per treatment between day 63 and 79 of the experiment. All photosynthesis measurements were conducted between 11 a.m. and 1 p.m. By multiplying $A_{\text {act }}$ with the length of the light period $(50,400 \mathrm{~s})$ and total leaf area, we obtained an estimate of net assimilation rate on a daily basis (NAR in mg C plant ${ }^{-1}$ day $^{-1}$ ).

\section{Statistical analyses}

All statistical analyses were carried out with SAS 8.02 software (Statistical Analysis System, SAS Institute Inc., Cary, USA). A Shapiro-Wilk test was used to test the data for normality of distribution; the homogeneity of variances was analysed by the Levene test. One-way ANOVAs were applied to test for significant differences in the growth parameters among the 16 treatments; a Tukey-Kramer test was used to locate significant differences among the treatment means. The ANOVA runs focussed either on the differences between the sub-plot factors soil moisture and nitrogen supply (under given air temperature and VPD regimes), or on the factors temperature and VPD under the same soil moisture and nitrogen regimes. For quantifying the relative influence of the four factors $T, \Theta$, VPD and $\mathrm{N}$ on the growth parameters, we applied a multiple analysis of variance (multiple GLM). In all cases, climate chamber effects were taken into account in the analysis by using a nested split-plot design (soil moisture and $\mathrm{N}$ supply nested within the air temperature and VPD treatments). These analyses did not reveal a significant chamber effect in our data set (results not shown).

Multiple linear regression analyses with stepwise forward variable selection were employed to investigate the influence (a) of leaf-related parameters (average leaf size, number of leaves, SLA) on total leaf area, and (b) of LAR, NAR, total leaf area, shoot-to-root ratio and foliar $\mathrm{N}$ concentration on plant dry matter production. In all analyses, significance was determined at $P<0.05$.

\section{Results}

Leaf area and its environmental control

All four environmental factors influenced the leaf area of the beech saplings, either through an effect on the plant's total leaf number or on average leaf size (Table 2). The number of leaves was affected in particular not only by soil moisture and nitrogen supply, and the interaction of these factors, but also by the prevailing saturation deficit of the air, while we found no effect of temperature on beech leaf numbers. With favourable soil moisture and nitrogen supply, the plants produced more than $30 \%$ additional leaves compared with the low soil moisture and low nitrogen treatments, in particular when growing in a moist and warm atmosphere $\left(\mathrm{VPD}=500 \mathrm{~Pa}\right.$ and $T=24^{\circ} \mathrm{C}$, 
Fig. 1a). In cooler and air-drier environments, the positive soil moisture and $\mathrm{N}$ effect on leaf numbers was smaller and not significant.

In contrast, average leaf size was primarily increased by a higher air temperature, while air humidity, soil moisture and nitrogen had no significant effect (except for the soil moisture $\times$ nitrogen interaction, Table 2). Under low VPD and high soil moisture and high $\mathrm{N}$ supply, the positive temperature effect on leaf size was particularly large and significant. At lower temperature $\left(18^{\circ} \mathrm{C}\right.$ during daytime, $10^{\circ} \mathrm{C}$ in the night), all treatments were more similar in average leaf size and the interactive soil moisture $\times$ nitrogen influence disappeared (Fig. 1b). A significant nitrogen effect on leaf size was only visible when VPD was small, soil moisture favourable and temperature elevated. In the treatments with lower temperature and drier soil, high $\mathrm{N}$ availability had no positive effect on leaf size, and rather tended to reduce leaf size than to increase it. Analysis of variance revealed that the interaction of $T$, VPD and $\mathrm{N}$ significantly influenced leaf size (Table 2).

Plant total leaf area, which equals leaf number $\times$ average leaf size, was correlated with all factors except VPD which had an only marginally significant effect $(P<0.1$, Table 2). As for the number of leaves, soil moisture and $\mathrm{N}$ had the largest explicatory value for total leaf area. The moderate temperature effect on total leaf area was intermediate between that on leaf size and leaf numbers. Multiple regression analysis indicated that the variation in leaf numbers had a far greater influence on total leaf area of the beech saplings than average leaf size (Table 3; partial $r^{2}=0.62$ and 0.34 ).

Morphological, physiological and environmental control of biomass production and the leaf areaproductivity relationship

All four environmental factors had a significant influence on the dry matter production of the beech saplings. The tightest correlation was detected for temperature, followed by soil moisture, air humidity and finally nitrogen supply (Table 2). However, the positive effect of elevated temperature was only significant if the saplings grew with favourable soil moisture and $\mathrm{N}$ supply. At lower temperature $\left(18 / 10^{\circ} \mathrm{C}\right)$, the effects of soil moisture, air humidity and $\mathrm{N}$ on productivity were weaker (Fig. 2a). At higher temperature and favourable $\mathrm{N}$ supply, low soil moisture led to a significant productivity reduction, but only if VPD was high. A high VPD itself had a significant negative effect on productivity under higher temperatures and favourable $\mathrm{N}$ supply, but low soil moisture. Finally, a significant positive effect of $\mathrm{N}$ supply on productivity was dependent on optimal $T, \Theta$, and VPD conditions. 
Fig. 1 Number of leaves, average leaf size and total leaf area of beech saplings grown for 87 days under controlled conditions in climate chambers. Mean and standard error of ten plants per treatment are given. $T$ air temperature, $V P D$ water vapour saturation deficit, $S 112$ vol.\% soil moisture, SO 6 vol.\% soil moisture, $N 1$ high nitrogen supply, NO low to moderate nitrogen supply. The four blocs are the climate chambers with a combination of two different temperatures and two different air humidity (VPD) regimes. Different lower case letters mark significant differences between treatments with different soil moisture and $\mathrm{N}$ supply (within-bloc variation). Significant differences between treatments with different temperatures and air humidities (between-bloc variation) are indicated by different capital letters in bars of the same contour. $P<0.05$ in all cases
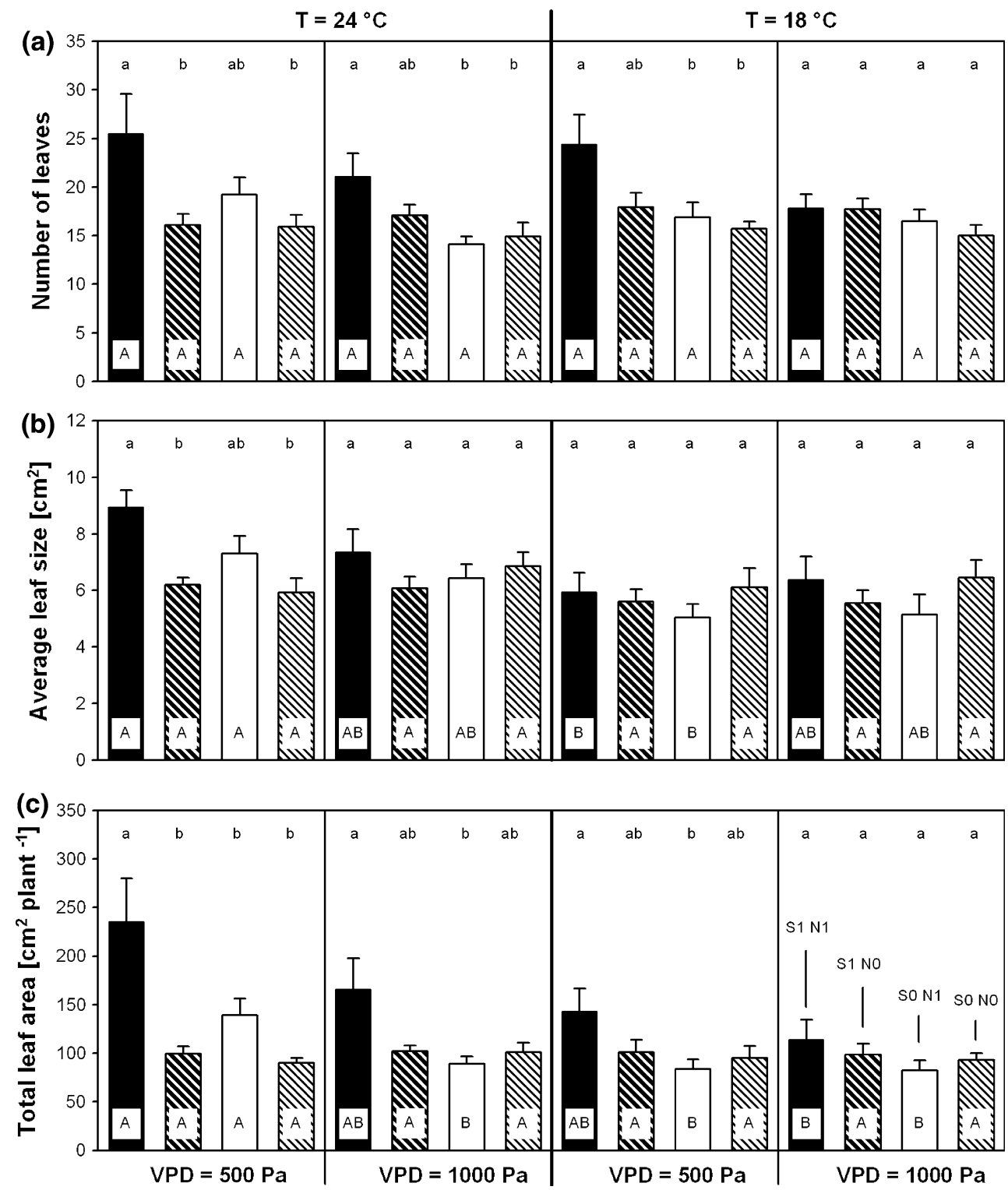

Shoot-to-root biomass ratio $(\mathrm{S} / \mathrm{R})$ remained stable across the treatments with values between 0.9 and 1.1 except for the $\mathrm{N}$ addition treatments which resulted in a large allocation shift from below- to aboveground biomass (Fig. 2b). Nitrogen effects on allocation were more pronounced under higher than lower temperature, resulting in significant $\mathrm{S} / \mathrm{R}$ increases at $24^{\circ} \mathrm{C}$ with high $\mathrm{N}$, if soil moisture was favourable. Multiple analysis of variance showed the dominant effect of $\mathrm{N}$ supply (10.9\% of variance in S/R explained) on aboveground/belowground partitioning, followed by the soil moisture influence $(6.2 \%$, data not shown). Under low soil moisture, the $\mathrm{N}$ effect on allocation was weaker and non-significant (Fig. 2b).

Specific leaf area (SLA, mean of all leaves) remained remarkably constant across the treatments under higher air temperature, but decreased under high $\mathrm{N}$ supply at lower temperature with high VPD (Fig. 2c). The SLA decrease was significant irrespective of soil moisture availability. Correspondingly, the multifactorial GLM revealed $\mathrm{N}$ supply and soil moisture to be principal controlling factors of SLA (Table 2). With respect to photosynthetic activity $\left(A_{\max }\right)$, the most important positive effect was exerted by a low VPD (Table 2). Under conditions of high air temperature and low VPD, $A_{\max }$ was found to be negatively influenced by high $\mathrm{N}$ supply in the shade-adapted beech saplings of our experiment (Table 3).

A multiple regression analysis, which related morphological (total leaf area, leaf area ratio, shoot-to-root ratio) and physiological parameters (photosynthetic activity expressed as net assimilation rate NAR, foliar $\mathrm{N}$ concentration) to productivity, showed that plant leaf area was by far the most important factor determining dry matter 
Table 3 Light-saturated net photosynthesis $\left(A_{\max }\right)$ and net assimilation rate (NAR) of beech saplings under controlled conditions in climate chambers

\begin{tabular}{|c|c|c|c|c|c|c|}
\hline \multirow{2}{*}{$\begin{array}{l}\text { Treatment } \\
\text { T1 VPD1 S1 N1 }\end{array}$} & \multicolumn{3}{|c|}{$A_{\max }\left(\mu \mathrm{mol} \mathrm{CO} \mathrm{CO}_{2} \mathrm{~m}^{-2} \mathrm{~s}^{-1}\right)$} & \multicolumn{3}{|c|}{ NAR (mg C plant ${ }^{-1}$ day $^{-1}$ ) } \\
\hline & $1.61 \pm 0.30$ & A & $\mathrm{b}$ & $69.47 \pm 14.74$ & A & $\mathrm{a}$ \\
\hline T1 VPD1 S1 N0 & $3.24 \pm 0.34$ & A & a & $57.08 \pm 7.98$ & A & A \\
\hline T1 VPD1 S0 N1 & $1.71 \pm 0.30$ & A & $\mathrm{b}$ & $34.07 \pm 6.55$ & A & A \\
\hline T1 VPD1 S0 N0 & $2.13 \pm 0.37$ & $\mathrm{~A}$ & $a b$ & $41.56 \pm 4.95$ & A & A \\
\hline T1 VPD0 S1 N1 & $1.62 \pm 0.30$ & A & $a b$ & $57.46 \pm 13.72$ & $\mathrm{AB}$ & A \\
\hline T1 VPD0 S1 N0 & $2.17 \pm 0.36$ & A & a & $48.75 \pm 8.13$ & A & $a b$ \\
\hline T1 VPD0 S0 N1 & $0.93 \pm 0.10$ & $\mathrm{~A}$ & $\mathrm{~b}$ & $18.45 \pm 2.87$ & A & B \\
\hline T1 VPD0 S0 N0 & $1.22 \pm 0.20$ & A & $a b$ & $32.08 \pm 4.83$ & A & $a b$ \\
\hline T0 VPD1 S1 N1 & $1.52 \pm 0.26$ & A & a & $51.09 \pm 7.91$ & $\mathrm{AB}$ & A \\
\hline T0 VPD1 S1 N0 & $2.15 \pm 0.27$ & $\mathrm{~B}$ & a & $43.73 \pm 7.57$ & A & A \\
\hline T0 VPD1 S0 N1 & $1.34 \pm 0.13$ & A & $\mathrm{a}$ & $28.99 \pm 5.44$ & A & A \\
\hline T0 VPD1 S0 N0 & $1.59 \pm 0.16$ & A & a & $31.87 \pm 7.23$ & A & A \\
\hline T0 VPD0 S1 N1 & $1.16 \pm 0.18$ & A & a & $25.45 \pm 4.57$ & $\mathrm{~B}$ & A \\
\hline T0 VPD0 S1 N0 & $1.31 \pm 0.22$ & $\mathrm{~B}$ & a & $48.22 \pm 9.36$ & A & A \\
\hline T0 VPD0 S0 N1 & $1.30 \pm 0.23$ & A & $\mathrm{a}$ & $31.68 \pm 5.12$ & A & A \\
\hline T0 VPD0 S0 N0 & $1.47 \pm 0.26$ & A & $\mathrm{a}$ & $33.41 \pm 4.64$ & A & A \\
\hline
\end{tabular}

$A_{\max }$ was measured on days 80-87 of the experiment; NAR was calculated from photosynthetic rate under ambient chamber conditions, measured on days 63-79 of the experiment. Due to full shade-adaptation, $A_{\max }$ was relatively low. Mean and standard error of ten plants per treatment are given. $\mathrm{T} 1=24^{\circ} \mathrm{C}$ air temperature, $\mathrm{T} 0=18^{\circ} \mathrm{C}$ air temperature, VPD $1=500 \mathrm{~Pa}$ water vapour saturation deficit, $\mathrm{VPD} 0=1,000 \mathrm{~Pa}$ water vapour saturation deficit, $\mathrm{S} 1=12$ vol. $\%$ soil moisture, $\mathrm{S} 0=6 \mathrm{vol} . \%$ soil moisture, N1 $=$ high nitrogen supply, N0 = low to moderate nitrogen supply. Different lower case letters mark significant differences between treatments with different soil moisture and $\mathrm{N}$ supply (within-bloc variation). Significant differences between treatments with different temperatures and air humidities (between-bloc variation) are indicated by different capital letters. $P<0.05$ in all cases

production (partial $r^{2}=0.59$ ), while photosynthetic activity had only a weak influence (partial $r^{2}=0.03$, Table 4). A significant influence was also found for leaf area ratio, which is plant total leaf area per unit total plant dry mass. In contrast, the explicatory value of $\mathrm{S} / \mathrm{R}$ ratio and $\mathrm{N}_{\text {leaf }}$ for productivity was negligible.

\section{Discussion}

Environmental control of productivity

Our study in four large climate chambers with precise environmental control provided evidence that each of the four tested factors alone influenced the productivity of beech saplings, and it also proved the importance of factor interactions. Clearly, our four-factorial experiment simulated a onestep change in the environmental conditions only, which may indicate the direction of growth change and its magnitude, but not the precise growth response to alterations in $T, \Theta$, VPD and $\mathrm{N}$. Our results about single-factor effects on productivity are mostly in line with earlier physiological studies on F. sylvatica saplings. Pronounced productivity stimulation by higher temperatures was found in various studies on beech (e.g. Piutti and Cescatti 1997; Bruhn et al. 2000; Fotelli et al.
2005; Saxe and Kerstiens 2005; Overdieck et al. 2007). Our data show a productivity increase by about $60 \%$ with a $6^{\circ} \mathrm{C}$ temperature increase (means of all treatments at 18 and $24^{\circ} \mathrm{C}$ ) which matches well with the results of Overdieck et al. (2007) who reported a $50 \%$ productivity increase in $F$. sylvatica saplings with a temperature increase by $4^{\circ} \mathrm{C}$.

Similarly, our results on a soil moisture effect support earlier reports about beech saplings to be drought sensitive (e.g. Madsen and Larsen 1997; Fotelli et al. 2001; Rose et al. 2009). In the elevated temperature treatment $\left(24^{\circ} \mathrm{C}\right)$, the productivity was reduced by $40 \%$ when exposed to 6 vol.\% instead of 12 vol.\% soil moisture. Our study further showed that the atmospheric saturation deficit acts as a soil water-independent growth-influencing factor, as the growth-reducing effect of high VPD levels was evident at both high and at low soil water availability. In support of this result, Lendzion and Leuschner (2008) obtained similar results in a climate chamber experiment where the beech sapling were grown in hydroponic culture with unlimited soil moisture supply and also in an air humidity manipulation experiment in the field using open-top chambers. In our experiment, the VPD regime was also found to alter the response of beech productivity to soil moisture, temperature and nitrogen, i.e. to act directly and indirectly on growth. 
Fig. 2 Dry matter production, shoot-to-root ratio and specific leaf area of beech saplings grown for 87 days under controlled conditions in climate chambers. Mean and standard error of ten plants per treatment are given. For abbreviations and explanations see Fig. 1
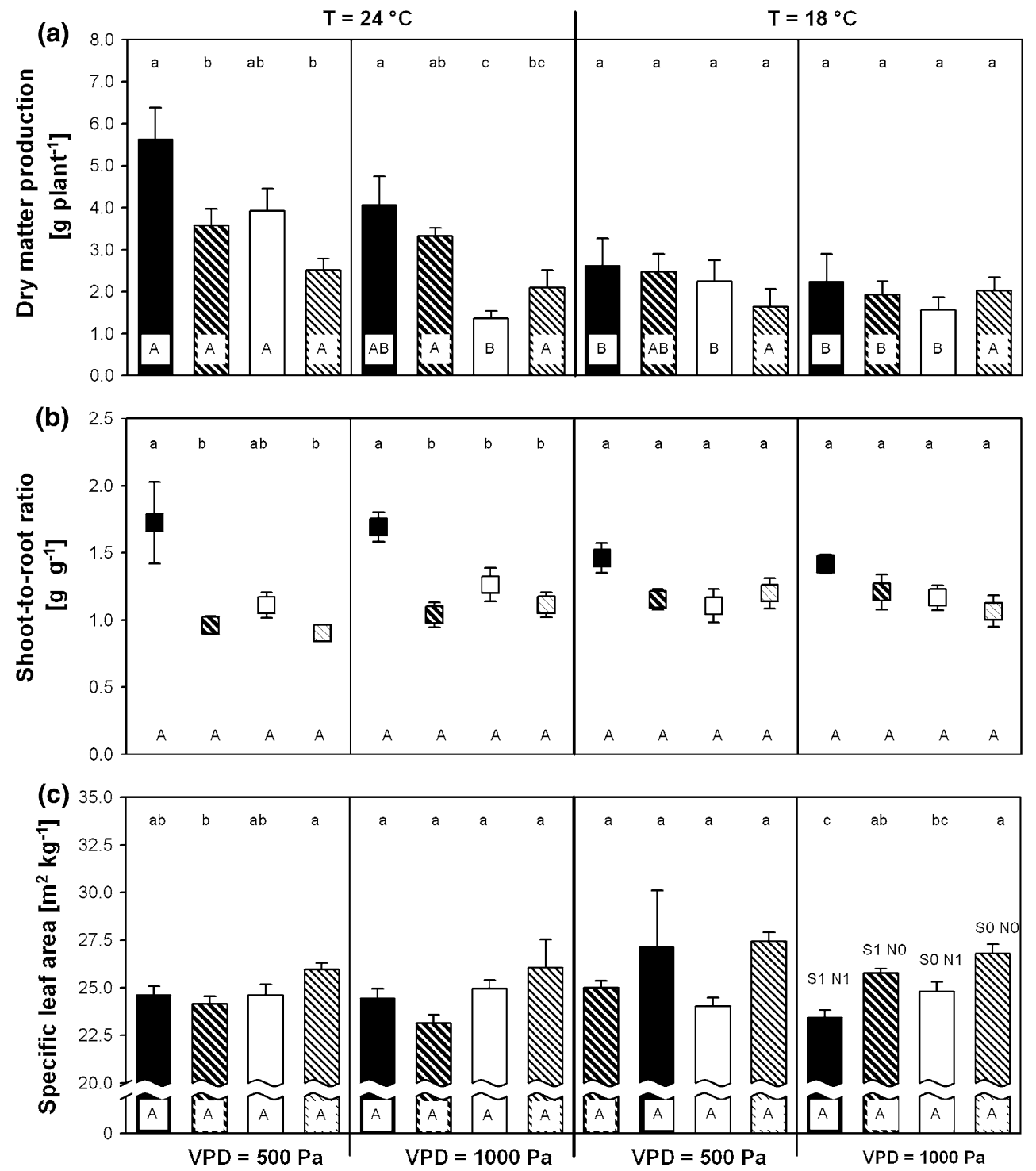

Table 4 (a) Multiple regression analysis with forward variable selection on the influence of the number of leaves, average leaf size and specific leaf area on a plant's total leaf area. (b) Results of multiple regression analysis with forward variable selection on the influence of total leaf area, LAR, NAR, shoot-to-root ratio and the foliar $\mathrm{N}$ concentration on the dry matter production of beech saplings

\begin{tabular}{|c|c|c|c|c|c|}
\hline & Predictor & Partial $r^{2}$ & Parameter estimate & $F$ statistic & $P$ value \\
\hline \multirow[t]{3}{*}{ (a) Total leaf area ${ }^{a}$} & Intercept & & -155.497 & & \\
\hline & Number of leaves & 0.6220 & 7.616 & 259.96 & $<0.0001$ \\
\hline & Average leaf size & 0.3414 & 19.706 & 146.86 & $<0.0001$ \\
\hline \multirow[t]{5}{*}{ (b) Dry matter production ${ }^{\mathrm{b}}$} & Total leaf area & 0.5907 & 0.0234 & 225.15 & $<0.0001$ \\
\hline & LAR & 0.1559 & -0.0357 & 95.32 & $<0.0001$ \\
\hline & NAR & 0.0291 & 12.4117 & 20.00 & $<0.0001$ \\
\hline & Shoot-to-root ratio & 0.0099 & -0.5856 & 7.05 & 0.0088 \\
\hline & $\mathrm{N}_{\text {leaf }}$ & 0.0085 & 0.9577 & 6.27 & 0.0133 \\
\hline
\end{tabular}

Given are the partial $r^{2}$, the parameter estimate, the $F$ statistic and the probability $P$ of error for the selected predictors

${ }^{a}$ The $r^{2}$ of the model was 0.9634

b The $r^{2}$ of the model was 0.7941 
The multiple analyses of variance indicated that factor interactions exerted significant influences on the productivity parameters as well. For example, the interaction of soil moisture and nitrogen availability significantly influenced total leaf area and leaf size, as the interaction of temperature, VPD and $\mathrm{N}$ did; dry matter production was influenced by this interaction in a similar way.

Some of the factor interactions were synergistic, i.e. the effect on the growth parameters was larger than the added effects of the isolated factors. For example, productivity increased with a temperature increase from 18 to $24^{\circ} \mathrm{C}$ by about $80 \%$, and with a VPD reduction from 1,000 to $500 \mathrm{~Pa}$ by about $16 \%$. However, when both parameters were changed synchronously in the $24^{\circ} \mathrm{C} / 500 \mathrm{~Pa}$ treatment, productivity was about $150 \%$ higher than in the $18^{\circ} \mathrm{C} /$ $1,000 \mathrm{~Pa}$ treatment, which is substantially more than the added temperature and air humidity effects. In European beech, synergy effects were also observed for the combination of temperature and $\left[\mathrm{CO}_{2}\right]$ (Saxe and Kerstiens 2005; Bruhn et al. 2000), temperature and light (Fotelli et al. 2005) as well as for the light/soil fertility interaction (Johnson et al. 1997). These results underline the importance of multi-factor studies when attempting to predict the response of trees to climatic changes. Whether two or more factors interact in a synergistic way or not, depends not only on the factors but also on the species. Pine and birch seedlings, for example, revealed, in contrast to beech, no positive interaction of the temperature and $\left[\mathrm{CO}_{2}\right]$ effects (Teskey 1997; Kellomäki and Wang 2001).

Another result of our four-factorial experiment is that all factors caused larger productivity stimulation when all (or most) other factors reached favourable conditions. The positive growth effect of a $6^{\circ} \mathrm{C}$-temperature increase was largest with high $\mathrm{N}$ supply, favourable soil moisture and elevated air humidity, but disappeared in dry soil and at low to moderate N supply. Similarly, a significant nitrogen effect on productivity appeared only when temperature, soil moisture and air humidity were high. On the other hand, the temperature reduction to $18^{\circ} \mathrm{C}$ reduced the soil moisture and $\mathrm{N}$ effects on productivity to become insignificant. Our findings can be judged as experimental support for Liebig's hypothesis on plant productivity being limited by a single factor only in a given environmental setting. Again, these results highlight the necessity to investigate plant responses in the context of all (or most) relevant factors. Interaction with additional factors not considered in a study is a very likely explanation for opposing results obtained in many single-factor experiments on tree-environment relationships. For example, various studies obtained contrasting results on the drought response of beech saplings and associated productivity reductions and allocation shifts (Tognetti et al. 1995; Löf et al. 2005; Fotelli et al. 2001).
While climate chamber experiments may help to disentangle the web of interacting environmental factors regulating the growth of juvenile trees, it is questionable whether these findings can be transferred to adult trees in the field. Clearly, our experiment neglected other possible growth-regulating factors, (such as biotic interactions, light, $\mathrm{P}$ availability or $\left[\mathrm{CO}_{2}\right]$ ) and it ignored that environmental factors fluctuate over time with extreme conditions being often more influential than the means.

\section{Regulation of leaf area at the plant level}

Two processes regulate the size of a plant's total leaf area: the initiation of leaf primordia in apical meristems which determines the number of leaves, and leaf expansion regulating leaf surface area. The issue how many leaf buds are formed and to what size the leaves expand is determined partly by genetic constraints and partly by environmental conditions. In the forest, beech leaf primordia are typically initiated in summer, but unfold only in April/May of the subsequent year (Eschrich 1995). Since the two processes occur non-synchronously, it is likely that they are sensitive to different environmental factors. In our experiment, in contrast, the phenological rhythm of beech with determinate leaf flushing in spring was overridden by constant radiation and temperature conditions. When transferred to the climate chambers, the beech saplings had only 3-4 leaf buds on average, but continued to develop 1 to $>20$ additional leaf buds during the 3-month experimental period. Thus, the bulk of leaf buds were formed in the climate chambers under the same environmental conditions as were influential during leaf expansion. The results of our study demonstrate that both processes must be sensitive to different environmental factors in beech saplings with leaf bud initiation mainly influenced by soil moisture and $\mathrm{N}$ supply, while leaf expansion being primarily dependent on temperature and only to a smaller extent on the interaction of soil moisture and $\mathrm{N}$. The predominant temperature influence on leaf expansion may come as a surprise since it has long been assumed that leaf cell turgor, and hence water supply acts as main environmental determinant of leaf expansion (e.g. Hsiao 1973). However, subsequent research has demonstrated that leaf growth may be inhibited by processes other than turgor loss as well including changes in cell wall extensibility (Bogoslavsky and Neumann 1998) and alteration in membrane transport processes that are temperature-dependent (van Volkenburgh 1999). In fact, neither soil moisture nor air humidity had a significant effect on the average leaf size of the saplings; soil moisture shortage did not decrease, but rather increase, specific leaf area. While the causes of the small soil moisture effect on average leaf size remain unclear, it is evident that the water and nitrogen effects on leaf 
expansion were overridden in our experiment by the large temperature effect. Accordingly, soil moisture, N supply and the air humidity regime are influencing the total leaf area of beech sapling through effects on leaf bud formation, but not on leaf expansion, which depended mainly on temperature. Light, which influences cell expansion through several mechanisms (van Volkenburgh 1999), was not a variable in our experiment, but certainly plays an important role as well.

\section{Conclusions}

Our four-factorial experiment demonstrated that leaf bud formation, i.e. the initiation of leaf primordia, is a more important determinant of total leaf area than leaf expansion in 1-year-old beech saplings. How many leaf buds are formed, is also a key process controlling productivity since dry matter production was found to be primarily dependent on leaf area, while the influence of photosynthetic activity was of minor importance. Leaf bud formation and leaf expansion were found to be controlled by different environmental factors with soil moisture, $\mathrm{N}$ supply and the air humidity regime regulating leaf area mostly through effects on leaf bud formation, and not on leaf expansion growth, which was found to be mainly under temperature (and probably light) control. This is supporting evidence for our second hypothesis. Our study further provided evidence for a number of factor interactions in the control of leaf area and productivity of beech saplings that are neglected in single-factor studies, but need to be considered when predicting the growth and vitality response of $F$. sylvatica offspring under a changing climate. Research on the biological consequences of climate or land use change needs to consider at least four key environmental factors (temperature, soil moisture, nitrogen supply and $\left[\mathrm{CO}_{2}\right]$ ), but should investigate the effects of alterations in air humidity levels as well, which exerted a significant, soil moisture-independent effect on productivity in this study as was postulated in our first hypothesis. Multi-factorial experiments under field conditions represent the next step in the experimental analysis of growth responses of woody plants to complex climatic changes.

Acknowledgments We thank Norbert Hölzel for helpful statistical comments and Heinz Coners for technical assistance. Further, the Richard-Winter-Stiftung is acknowledged for financial support of Ann-Catrin Fender during the experimental period.

Open Access This article is distributed under the terms of the Creative Commons Attribution Noncommercial License which permits any noncommercial use, distribution, and reproduction in any medium, provided the original author(s) and source are credited.

\section{References}

Baumeister W, Ernst W (1978) Mineralstoffe und Pflanzenwachstum, 3rd edn. Fischer, Stuttgart

Bazzaz FA, Miao SL (1993) Successional status, seed size, and responses of tree seedlings to $\mathrm{CO}_{2}$, light, and nutrients. Ecology 74:104-112

Bogoslavsky N, Neumann PM (1998) Rapid regulation by acid pH of cell wall adjustment and leaf growth in maize plants responding to reversal of water stress. Plant Physiol 118:701-709

Bruhn D, Leverenz JW, Saxe H (2000) Effects of tree size and temperature on relative growth rate and its components of Fagus sylvatica seedlings exposed to two partial pressures of atmospheric $\mathrm{CO}_{2}$. New Phytol 146:415-425

Cernusek LA, Winter K, Aranda J, Virgo A, Garcia M (2009) Transpiration efficiency over an annual cycle, leaf gas exchange and wood carbon isotope ratio of three tropical tree species. Tree Physiol 29:1153-1161

Closa I, Irigoyen JJ, Goiceochea N (2010) Microclimatic conditions determined by stem density influence leaf anatomy and leaf physiology of beech (Fagus sylvatica L.) growing within stands that naturally regenerate from clear-cutting. Trees 24:1029-1043

Eschrich W (1995) Funktionelle Pflanzenanatomie. Springer, Berlin

Faria T, Wilkins D, Besford RT, Vaz M, Pereira JS, Chaves MM (1996) Growth at elevated $\mathrm{CO}_{2}$ leads to down-regulation of photosynthesis and altered response to high temperature in Quercus suber L. seedlings. J Exp Bot 47:1755-1761

Finzi AC, Canham CD (2000) Sapling growth in response to light and nitrogen availability in a southern New England forest. For Ecol Manage 131:153-165

Flückiger W, Braun S (1999) Nitrogen and its effects on growth, nutrient status, parasite attacks in beech and Norway spruce. Water Air Soil Pollut 116:99-110

Fotelli MN, Radoglou KM, Constantinidou H-IA (2000) Water stress responses of seedlings of four Mediterranean oak species. Tree Physiol 20:1065-1075

Fotelli MN, Geßler N, Peuke AD, Rennenberg H (2001) Drought affects the competitive interactions between Fagus sylvatica seedlings and an early successional species, Rubus fruticosus: responses of growth, water status and $\delta{ }^{13} \mathrm{C}$ composition. New Phytol 151:427-435

Fotelli MN, Rudolph P, Rennenberg H, Geßler A (2005) Irradiance and temperature affect the competitive interference of blackberry on the physiology of European beech seedlings. New Phytol 165:453-462

García-Plazaola JI, Becerril JM (2000) Effects of drought on photoprotective mechanisms in European beech (Fagus sylvatica L.) seedlings from different provenances. Trees 14:485-490

Geßler A, Schneider S, von Sengbusch D, Weber P, Hanemann U, Huber C, Rothe A, Kreutzer K, Rennenberg H (1998) Field and laboratory experiments on net uptake of nitrate and ammonium by the roots of spruce (Picea abies) and beech (Fagus sylvatica) trees. New Phytol 138:275-285

Heath J, Kerstiens G (1997) Effects of elevated $\mathrm{CO}_{2}$ on leaf gas exchange in beech and oak at two levels of nutrient supply: consequences to sensitivity to drought in beech. Plant Cell Environ 20:57-67

Hsiao TC (1973) Plant responses to water stress. Am J Plant Physiol 24:519-570

IPCC (2007) Summary for policymakers. In: Solomon S, Qin D, Maning M, Chen Z, Marquis M, Averyt KB, Tignor M, Miller HL (eds) Climate Change 2007: the physical science basis. Contribution of working group I to the fourth assessment report of the intergovernmental panel on climate change. University Press, Cambridge 
Johnson JD, Tognetti R, Michelozzi M, Pinzauti S, Minotta G, Borghetti M (1997) Ecophysiological responses of Fagus sylvatica seedlings to changing light conditions. 2 . The interaction of light environment and soil fertility on seedling physiology. Physiol Plant 101:124-134

Kellomäki S, Wang K-Y (2001) Growth and resource use of birch seedlings under elevated carbon dioxide and temperature. Ann Bot 87:669-692

Kozovits AR, Matyssek R, Blaschke H, Göttlein A, Grams TEE (2005) Competition increasingly dominates the responsiveness of juvenile beech and spruce to elevated $\mathrm{CO}_{2}$ and/or $\mathrm{O}_{3}$ concentrations throughout two subsequent growing seasons. Glob Chang Biol 11:1387-1401

Kriebitzsch WU, Grimme K, Regel J (1985) Über den $\mathrm{H}_{2} \mathrm{O}$ Gaswechsel von Mercurialis perennis im submontanen Kalkbuchenwald. II. Der Jahresgang der Transpiration in Abhängigkeit von steuernden Parametern. Flora 177:351-368

Lendzion J, Leuschner C (2008) Growth of European beech (Fagus sylvatica L.) saplings is limited by elevated vapour pressure deficits. For Ecol Manage 256:648-655

Lendzion J, Leuschner C (2009) Temperate forest herbs are adapted to high air humidity - evidence from climate chamber and humidity manipulation experiments in the field. Can J For Res 39:2332-2342

Leverenz JW, Bruhn D, Saxe H (1999) Responses of two provenances of Fagus sylvatica seedlings to a combination of four temperature and two $\mathrm{CO}_{2}$ treatments during their first growing season: gas exchange of leaves and roots. New Phytol 144:437-454

Löf M, Welander NT (2000) Carry-over effects on growth and transpiration in Fagus sylvatica seedlings after drought at various stages of development. Can J For Res 30:468-475

Löf M, Bolte A, Welander T (2005) Interacting effects of irradiance and water stress on dry weight and biomass partitioning in Fagus sylvatica seedlings. Scand J Forest Res 20:322-328

Madsen P (1995) Effects of soil water content, fertilization, light, weed competition and seedbank type on natural regeneration of beech (Fagus sylvatica). For Ecol Manage 72:251-264

Madsen P, Larsen JB (1997) Natural regeneration of beech (Fagus sylvatica L.) with respect to canopy density, soil moisture and soil carbon content. For Ecol Manage 97:95-105

Magnani F, Mencuccini M, Borghetti M, Berbigier P, Berninger F, Delzon S, Grelle A, Hari P, Jarvis PG, Kolari P, Kowalski AS, Lankreijer H, Law BE, Lindroth A, Loustau D, Manca G, Moncrieff JB, Rayment M, Tedeschi V, Valentini R, Grace J (2007) The human footprint in the carbon cycle of temperate and boreal forests. Nature 44:848-850

Nielsen CN, Jørgensen FV (2003) Phenology and diameter increment in seedlings of European beech (Fagus sylvatica L.) as affected by different soil water contents: variation between and within provenances. For Ecol Manage 174:233-249
Overdieck D, Ziche D, Böttcher-Jungclaus K (2007) Temperature responses of growth and wood anatomy in European beech saplings grown in different carbon dioxide concentrations. Tree Physiol 27:261-268

Palátová E (2002) Effect of increased nitrogen depositions and drought stress on the development of Scots pine (Pinus sylvestris L.) - II. Root system response. J For Sci 48:237-247

Peuke AD, Schraml C, Hartung W, Rennenberg H (2002) Identification of drought-sensitive beech ecotypes by physiological parameters. New Phytol 154:373-387

Piutti E, Cescatti A (1997) A quantitative analysis of the interactions between climatic response and intraspecific competition in European beech. Can J For Res 27:277-284

Rodenkirchen H, Göttlein A, Kozovits AR, Matyssek R, Grams TEE (2009) Nutrient contents and efficiencies of beech and spruce saplings as influenced by competition and $\mathrm{O}_{3} / \mathrm{CO}_{2}$ regime. Eur J Forest Res 128:117-128

Rose L, Leuschner C, Köckemann B, Buschmann H (2009) Are marginal beech (Fagus sylvatica L.) provenances a source for drought tolerant ecotypes? Eur J For Res 128:335-343

Saxe H, Kerstiens G (2005) Climate change reverses the competitive balance of ash and beech seedlings under simulated forest conditions. Plant Biol 7:375-386

Schär C, Vidale PL, Lüthi D, Frei C, Häberli C, Liniger MA, Appenzeller C (2004) The role of increasing temperature variability in European summer heatwaves. Nature 427:332-336

Sefcik LT, Zak DR, Ellsworth DS (2007) Seedling survival in a northern temperate forest understory is increased by elevated atmospheric carbon dioxide and atmospheric nitrogen deposition. Glob Chang Biol 13:132-146

Teskey RO (1997) Combined effects of elevated $\mathrm{CO}_{2}$ and air temperature on carbon assimilation of Pinus taedea trees. Plant Cell Environ 20:373-380

Thomas VFD, Braun S, Flückiger F (2006) Effects of simultaneous ozone exposure and nitrogen loads on carbohydrate concentrations, biomass, growth, and nutrient concentrations of young beech trees (Fagus sylvatica). Environ Pollut 143:341-354

Tognetti R, Johnson JD, Michelozzi M (1995) The response of European beech (Fagus sylvatica L.) seedlings from two Italian populations to drought and recovery. Trees 9:348-354

van Hees AFM (1997) Growth and morphology of pedunculate oak (Quercus robur L.) and beech (Fagus sylvatica L.) seedlings in relation to shading and drought. Ann For Sci 54:9-18

van Volkenburgh E (1999) Leaf expansion-an integrating plant behaviour. Plant Cell Environ 22:1463-1473

Werner PC, Gerstengarbe F-W (2007) Welche Klimaänderungen sind in Deutschland zu erwarten? In: Endlicher W, Gerstengarbe F-W (eds) Klimawandel-Einblicke, Rückblicke und Ausblicke. G\&S Druck und Medien, Potsdam 